Brit. Heart F., 1967, 29, 276.

\title{
Osteoclastoma of the Heart
}

\author{
PAUL DORNEY
}

\author{
From the Royal Hobart Hospital, Hobart, Tasmania
}

Secondary tumours of the heart are common, and where death is due to cancer the rate is 6.2 per cent (Willis, 1934). However, primary cardiac neoplasms are much rarer, occurring only about once in 60,000 necropsies (Cecil-Loeb Textbook of Medicine, 1963).

About 35 per cent of primary heart tumours are myxomas, the remainder being angiomas, rhabdomyomas, leiomyomas, and their malignant counterparts (Yater, 1931). Most of these tumours occur in the 30-60 age-group and affect the sexes equally. While the myxomas occur mainly in the left atrium, the other varieties are more common in the right atrium where they may produce signs of obstruction in the superior vena cava. Malignant heart tumours tend to invade the pericardial sac, producing hæmopericardium.

The benign tumours found in association with tuberous sclerosis are probably examples of hamartoma rather than true neoplasia.

Heart tumours in animals are exceedingly rare. Lucké (1934) mentions a sarcoma in the heart of a turtle and a metastatic sarcoma in the heart of a crocodile. Multiplying ossifying cartilaginous nodules attached by fibrous pedicles within the left ventricles of rats were described by Farris, Yeakel, and Seitner (1946).

Cumming and Shillitoe (1957), reviewing the reported cases of primary tumours of blood vessels affecting the heart, found a sarcoma of the right pulmonary vein, four sarcomata of the pulmonary artery, and a primary myxosarcoma of the left auricle and pulmonary vein associated with multiple tumours of various types elsewhere in the body, and added an osteogenic sarcoma of their own, arising from the right pulmonary vein, which grew into the left atrium and occluded the mitral opening.

The heart tumour to be described is considered to be an example of an extraskeletal osteoclastoma

Received August 2, 1966. arising from the interatrial septum. The writer is unaware of any similar case.

\section{CASE History}

The patient, aged 45, was first seen in October 1961. He gave a history of removal of a left parotid tumour in 1939 with a recurrence of this tumour in 1941, a temporary partial facial palsy developing after operation. The tumour, removed in 1939, was available for examination and microscopically it had the typical appearance of a mixed salivary tumour (Fig. 1). In 1958 a diagnosis of duodenal ulcer and hiatus hernia was made.

In 1961 his main symptoms were undue fatigue, epigastric pain, vomiting, and tachycardia. Occasionally there was chest pain and dyspnoea and these occurred mainly at night. The patient was somewhat incoherent and nervous, was a dietary faddist who never ate meat, and neither drank nor smoked.

On examination there was a late systolic bruit at the apex. The pulse was regular at 106 a minute and of smallish volume. The jugular venous pressure was doubtfully raised. The liver was enlarged two finger breadths below the costal margin and it was thought there was a mass in the epigastrium. Blood pressure was $115 / 60 \mathrm{~mm} . \mathrm{Hg}$. There was no clubbing, jaundice, anæmia, cyanosis, or peripheral œdema. All other systems were normal as were blood counts and differential counts; and serum electrolytes, alkaline phosphatase, urea, bilirubin, and total protein were within normal limits. The chest $x$-ray film and electrocardiogram were normal.

A diagnosis of carcinoma of the stomach was made and laparotomy was performed but showed only a large congested liver. Edema of the lower limbs developed after operation and this was thought to be nutritional in origin.

The writer first saw this man three weeks later when he had œdema of the lower limbs, a normal jugular venous pressure, and no evidence of right or left heart strain on clinical examination or in the electrocardiogram. There was a grade I mid-systolic bruit. The chest $x$-ray film was normal and no abnormality was detected in the heart or lungs. 
Six weeks later the heart showed moderate enlargement and the lung fields showed evidence of pulmonary œdema. The jugular venous pressure was raised to 5 $\mathrm{cm}$. and later readings were $2 \mathrm{~cm}$. and $3 \mathrm{~cm}$. Pulmonary œdema increased and jaundice developed. At this stage it was evident there was obstruction to pulmonary venous outflow and to upper and lower vena caval inflow, and this could only be explained by a primary heart tumour involving both atria. No further investigations were made and the patient died six weeks later.

Findings at Necropsy. The pericardium yielded 100 $\mathrm{ml}$. of clear yellow fluid. The heart weighed $620 \mathrm{~g}$. The whole of the interatrial septum was replaced by tumour tissue. On the right the tumour was irregular, firm, and white, with some superficial and deep hæmorrhages. It measured 5 by 5 by $4 \mathrm{~cm}$. It infiltrated the posterior wall of the atrium and extended into the inferior vena cava. On the left the tumour measured 6.5 by 7.5 by $5 \mathrm{~cm}$. with an irregular lobe $2 \mathrm{~cm}$. in diameter projecting through the mitral valve and partly obstructing it (Fig. 2).

The liver weighed $2100 \mathrm{~g}$. and showed gross nutmeg pattern. The spleen weighed $254 \mathrm{~g}$. and there were multiple small infarcts. The parotid gland was normal on the right side. There was scar tissue on the left side with no parotid gland visible. Other organs were normal for his age.

Histopathology. The heart tumour had a most remarkable appearance. Much of it was fibrous with areas of osteoid reaction; there were numerous giant cells of the osteoclastoma variety; and the largest had so many nuclei that over 200 could be counted in one plane. Details of the histopathology are shown in Fig. 3 and 4.

The sections were referred to Dr. Rupert Willis who reported as follows. "This pleomorphic cellular sarcoma has all the appearances of a malignant osteoclastoma and there is an indefinite suggestion of osteoid tissue here and there. The only one of its kind involving the heart, that I know of, was the ossifying sarcoma of a pulmonary vein occupying the left atrium reported by Cumming and Shillitoe."

Other consultant opinions were obtained (viz. E. W. Gault, R. Motteram, A. V. Jackson, A. A. Palmer, F. G. Hardy, L. R. Finlay Jones) and most agreed that this was probably an osteoclastoma.

\section{Discussion}

Although there can be little doubt that this is a heart tumour there must be some uncertainty as to whether it is a primary one, or a secondary from a primary of bone not found at necropsy, or from the parotid tumour that first appeared in 1939. Neither of these latter suppositions seems likely. It would be remarkable indeed for a bone sarcoma to fail to disclose its presence and to metastasize to the heart only. Similarly it would be remarkable for a parotid tumour to remain dormant and to appear 20 years later in the heart without any local or intermediate growth.

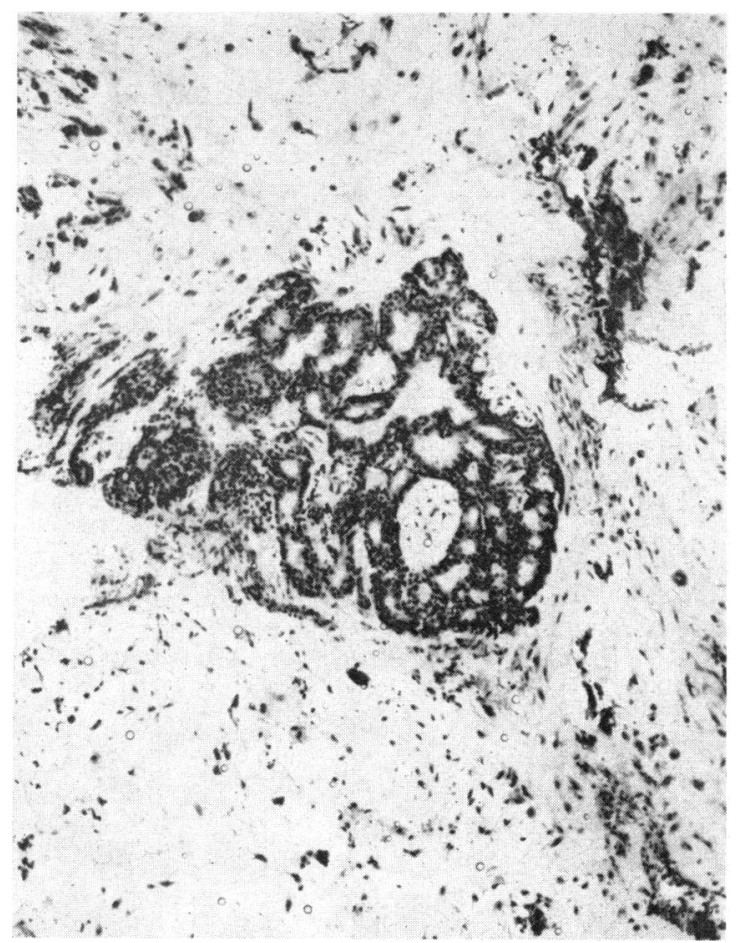

FIG. 1.-Parotid tumour (1939), showing the typical appearance of a mixed salivary tumour. $(\times 37 \cdot 5$.)

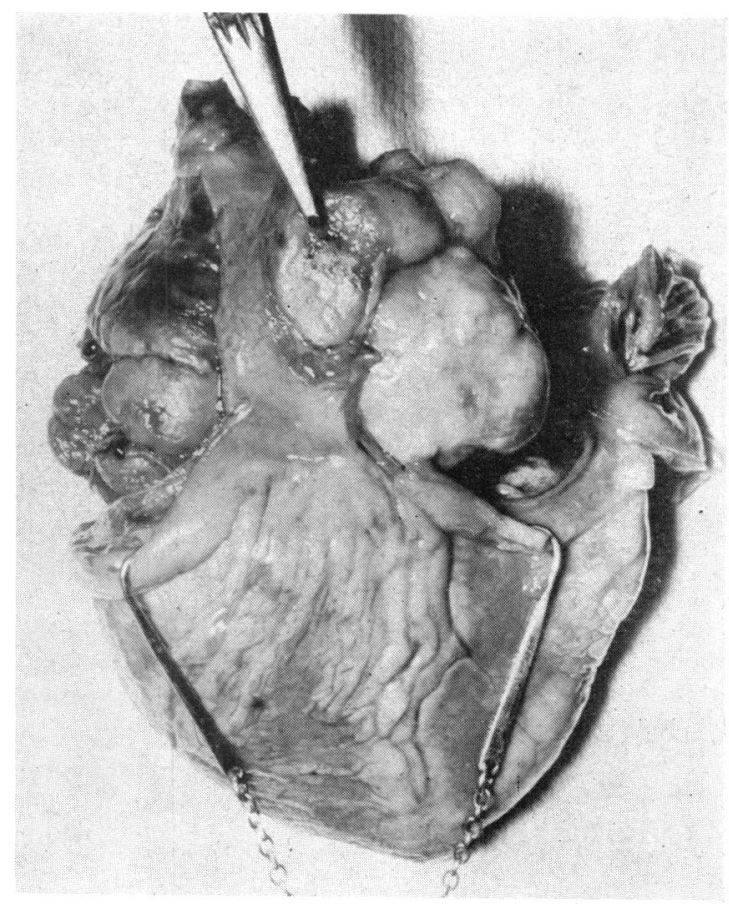

FIG. 2.-Heart, slightly reduced. The tumour can be seen bulging into the right and left atrial cavities. 


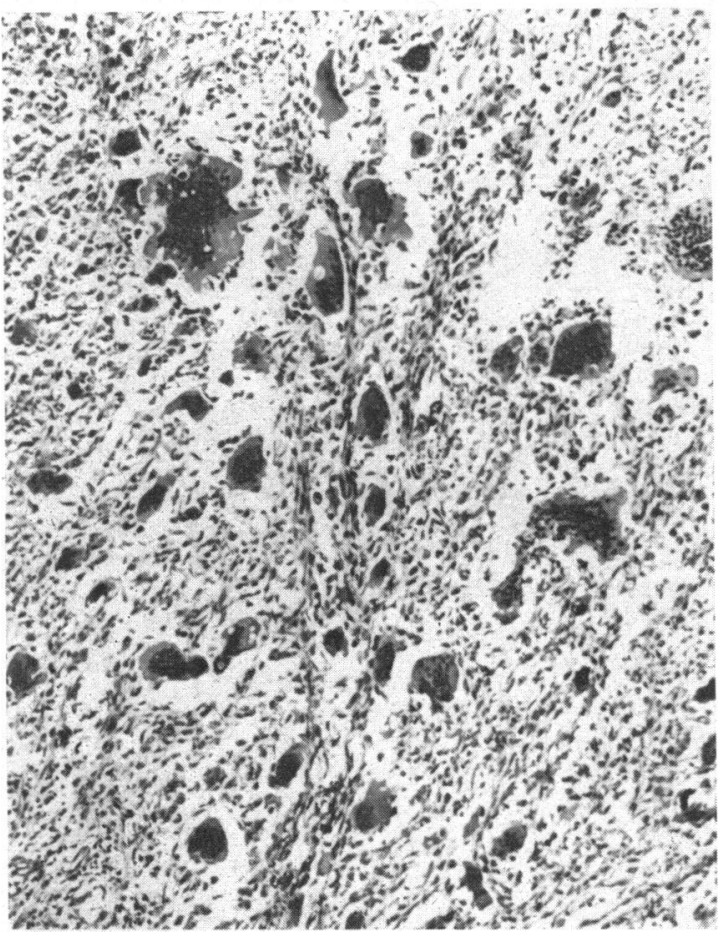

Fig. 3.-Heart tumour, showing numerous giant cells surrounded by spindle cells. $(\times 67 \cdot 5$.

The microscopical appearance of this tumour closely resembles the osteoclastomas of bone. The cells of the stroma and the giant cells in particular are characteristic. Foci of osteoid tissue in the tumour provide additional evidence.

Anderson (1961) wrote, "Although well recognized, malignant ossifying tumours originating in extraskeletal tissue and exhibiting clinical and pathological features comparable to those of conventional osteogenic sarcomas in bone are extremely rare. Arising primarily in skeletal muscle and deep fascial structures of the extremities, particularly the lower, a few have been encountered in other soft tissue sites including retroperitoneum and mediastinum."

A diagnosis of atrial heart tumour was considered during life and had angiocardiography been available at the time it might have revealed the correct diagnosis.

\section{SUMMARY}

A case of heart tumour in a man of 45 is presented. The tumour is considered to be primary, and is classified as an extraskeletal osteoclastoma. The

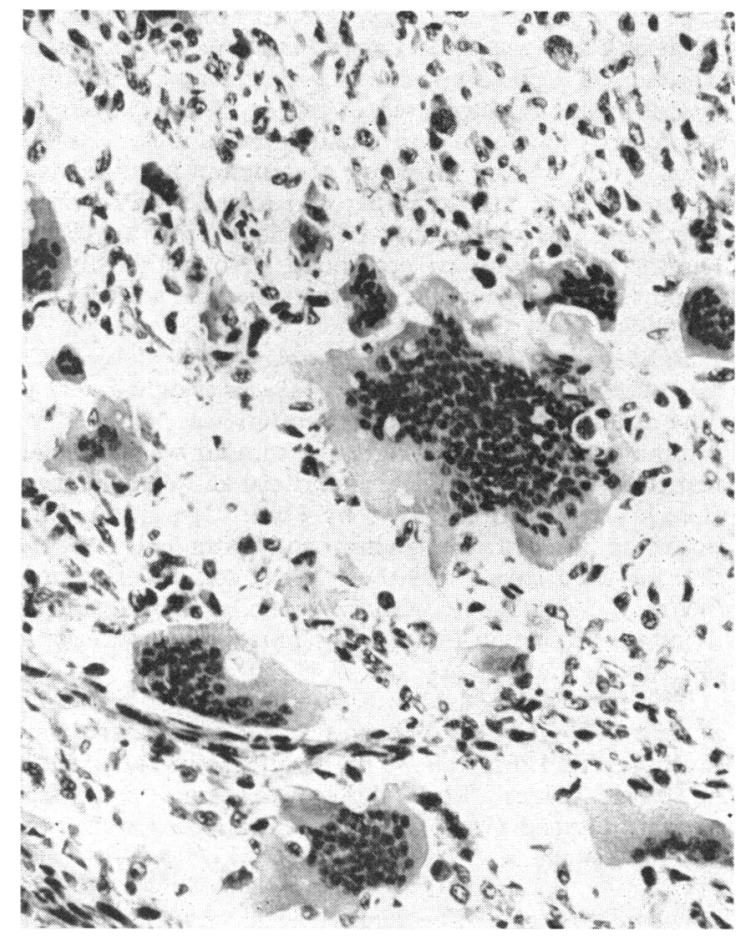

FIG. 4.-Heart tumour, showing the osteoclastoma-like giant cells with their numerous nuclei. $(\times 180$.)

diagnosis was considered during life but was not proven.

I am indebted to Dr. Mackay Smith for access to records at The Royal Hobart Hospital, to Dr. Peter Hamilton for the necropsy report, to Dr. Campbell Duncan for the photographs and for his most helpful suggestions, and to Dr. Keith Millingen for his permission to report the case which was under his care.

\section{REFERENCES}

Anderson, W. A. D. (1961). Pathology, 4th ed. Mosby, St. Louis.

Cecil-Loeb Textbook of Medicine (1963). 11th edn., ed. P. B. Beeson and W. McDermott. Saunders, Philadelphia and London.

Cumming, A. R. R., and Shillitoe, A. J. (1957). Ball-valve mitral obstruction by a sarcoma of a pulmonary vein. Brit. Heart f., 19, 287.

Farris, E. J., Yeakel, E. H., and Seitner, M. M. (1946). Ossifying cartilage and thrombi in the hearts of rats. Amer. F. Path., 22, 613.

Lucké, B. (1934). A neoplastic disease of the kidney of the frog, Rana pipiens. Amer. F. Cancer, 20, 352, and 22, 326.

Willis, R. A. (1934). The Spread of Tumours in the Human Body. Churchill, London.

Yater, W. M. (1931). Tumors of the heart and pericardium; pathology, symptomatology and report of nine cases. Arch. intern. Med., 48, 627. 